\title{
Эколого-географический анализ видов рода Geranium L. Алтайской горной страны
}

\section{Ecological and geographical analysis of species of the genus Geranium L. of the Altay mountain country}

\author{
Трошкина В. И. \\ Troshkina V. I. \\ Центральный сибирский ботанический сад СО РАН, г. Новосибирск, Россия. E-mail: vitroshkina@csbg.nsc.ru \\ Central Siberian Botanical garden SB RAS, Novosibirsk, Russia
}

\begin{abstract}
Peфepam. В работе проводится эколого-географический анализ видов рода Geranium L. Алтайской горной страны (АГС). Рассматривается распределение видов по ботанико-географическим районам АГС, распределение по типам ареалов и эколого-ценотическим условиям. Показано, что Алтайская горная страна является одним из центров разнообразия рода Geranium.
\end{abstract}

Ключевые слова. Алтайская горная страна, ареал, флористический комплекс Geranium, Geraniaceae.

Summary. The article presents the ecological and geographical analysis of species of the genus Geranium L. from the Altai mountain country. Distribution of species according botanical and geographical areas of the Altai mountain country, according types of areas and ecological-cenotic conditions is considered. It is shown that the Altai mountain country is one of the centers of the genus Geranium variety.

Key words. Altai mountain country, area, Geranium, Geraniaceae, floristic complex.

Характер географического распространения таксона любого ранга и, в особенности, вида - один из важнейших ботанико-географических параметров, дающих ключ к пониманию его формирования и развития. Общие очертания ареала вида и положение границ его на отдельных участках ареала, особенности распределения вида на занимаемой территории находятся в определенной и сложной зависимости от геоисторических и физико-географических условий его развития, имеющих, наряду с общими, и определенные региональные закономерности (Кожевников, 2001).

Ареал рода Geranium L. охватывает территорию Европы, Азии (включая Японию и Тайвань), Индонезии, Австралии и Океании, Гавайских островов, Северной и Южной Америки, Макаронезии, Африки (Yeo, 1984; Aedo, Garmendia, Pando, 1998). Изучением ареалов отдельных видов рода Geranium и секций занимались E. Hultén (1968), H. Meusel et al. (1978), Г. А. Пешкова (1996), С. Aedo et al. (1998), Д. Ю. Цыренова (2007), В. И. Трошкина (2015; 2016а, б; 2017).

Основными центрами видового разнообразия рода являются горные районы Европы, Средиземноморья, Южной, Центральной и Северной Америки и Гавайские острова (Robertson, 1972; Yeo, 1973). Как отмечал М. Г. Попов (1983), род обладает универсальным (биполярным) распространением, то есть имеет биполярный дизъюнктивный умеренно-субтропический ареал. Вопрос о времени и месте зарождения исходного типа Geranium в настоящее время все еще остается открытым. Обширный ареал рода свидетельствует о его древности. Ископаемая пыльца гераней (phaeum-type) известна с верхнего миоцена (Müller, 1981). Учитывая это, можно предположить, что к указанному периоду род уже достиг уровня значительной дифференциации, и появление предковых форм уходит в более раннее время (Цыренова, 2007).

Целью нашей работы было проведение эколого-географического анализа представителей рода Geranium во флоре Алтайской горной страны (АГС). 
Для выявления особенностей географического распространения видов гераней на территории АГС мы изучили их разнообразие в отдельных районах АГС. В работе использовано ботанико-географическое районирование территории АГС, предложенное Р. В. Камелиным (1998, 2002, 2004, 2005).

Распределение видов по ботанико-географическим районам представлено на рис. 1, где: А - Алтае-Западносаянская горная провинция (районы: А1 - Северно-Алтайский, А2 - Северо-Восточно-Алтайский, А3 - Центрально-Алтайский, А4 - Чулышманский, А5 - Абакано-Джебашский, А6 - Хемчикский); КАД - Алтае-Джунгарская горная провинция (районы: КАД1 - Северо-Западно-Алтайский, КАД2 - Калбинский, КАД3 - Тарбагатайский, КАД4 - Саурский, КАД5 - Зайсанский, КАД6 - Бухтарминский, КАД7 - Маркаколь-Канасский, КАД8 - Черно-Иртышский, КАД9 - Алтае-Джунгарский); 3М, ЮМ - Тувинско-Монгольская провинция (районы: 3М1 - Чуе-Кобдосский, 3М2 - Цаган-Гольский, ЗМ3 - Кобдосско-Тонхильский, ЮМ - Южно-Монгольский).

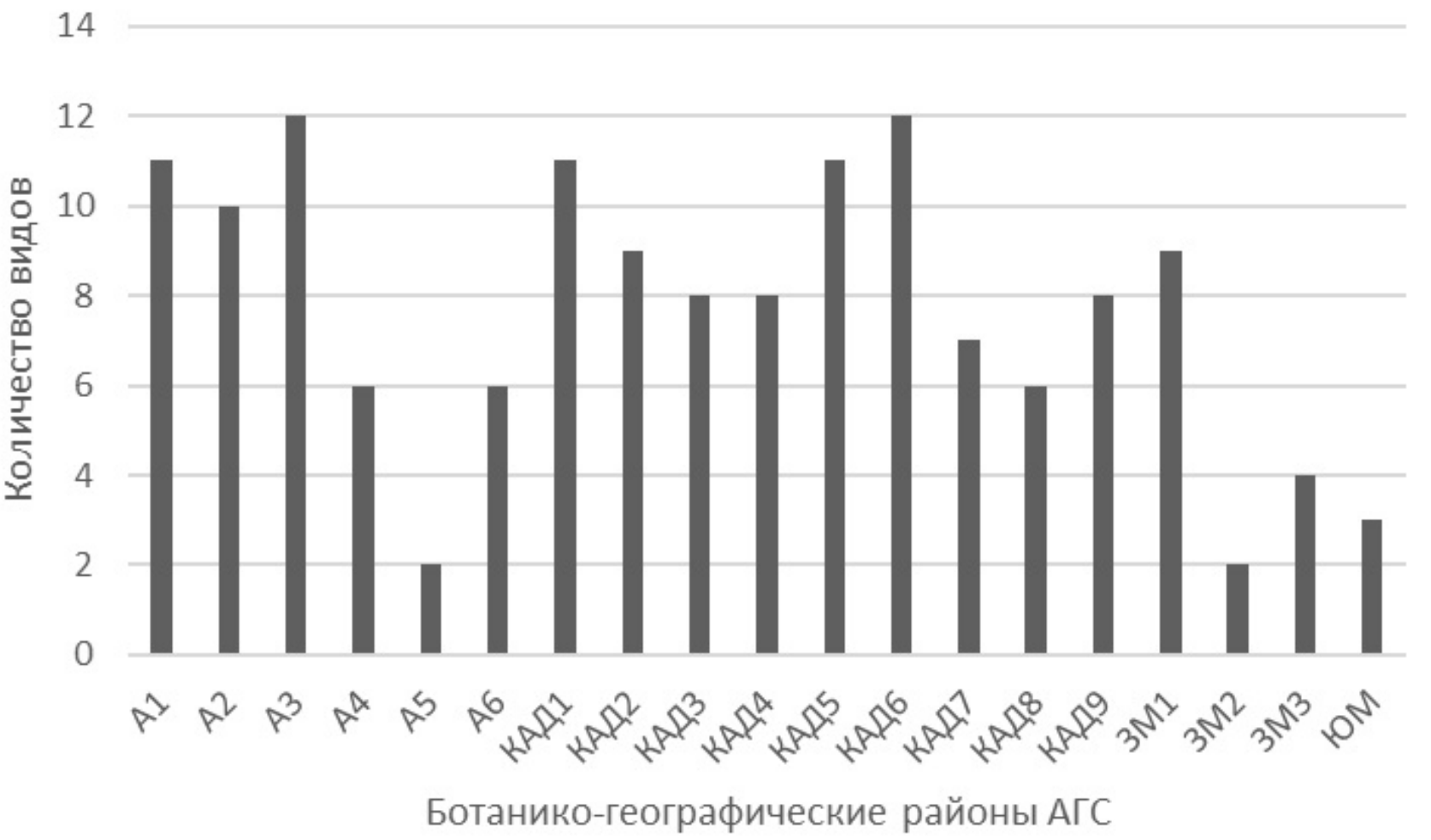

Рис. 1. Распространение видов рода Geranium в ботанико-географических районах Алтайской горной страны.

Наиболее богаты видами следующие районы: А3 (Центрально-Алтайский) и КАД6 (Бухтарминский) - по 12 видов; также богаты видами районы: А1 (Северно-Алтайский), КАД1 (Северо-Западно-Алтайский) и КАД5 (Зайсанский) - по 11 видов. Чуть менее богаты видами районы А2 (Северо-Восточно-Алтайский) - 10 видов и КАД2 (Калбинский) и ЗМ1 (Чуе-Кобдосский) - по 9 видов. Это можно объяснить не только лучшей изученностью этих районов, но и разнообразием представленных здесь комплексов: луговых, горно-лесных, горно-лугово-лесных, горно-лугово-степных, субальпийских редколесий, субальпийских и альпийских лугов и горных тундр.

Следующие районы содержат среднее число видов: КАД3 (Тарбагатайский), КАД4 (Саурский) и КАД9 (Алтае-Джунгарский) - по 8 видов; КАД7 (Маркаколь-Канасский) - 7 видов; А4 (Чулышманский), А6 (Хемчикский), КАД8 (Черно-Иртышский) - по 6 видов.

Маловидовые районы: 3М3 (Кобдосско-Тонхильский) - 4 вида; ЮМ (Южно-Монгольский) - 3 вида; А5 (Абакано-Джебашский) и 3М2 (Цаган-Гольский) - по 2 вида. Это можно объяснить слабой изученностью этих районов, а также более сухими климатическими условиями, не подходящими для мезофитных видов гераней. 
Изучение видового состава маловидовых районов показало, что из видов, встречающихся там, G. albiflorum, G. krylovii и G. pseudosibiricum являются криофитами, то есть растут на субальпийских и альпийских лугах, G. pratense и G. sergievskajae - являются мезоксерофитами, а G. collinum предпочитает засоленные местообитания, что как раз характерно для этих районов. В целом, видовое богатство гераней АГС уменьшается в юго-восточном направлении, где преобладают более засушливые районы.

При выделении групп и типов ареала мы использовали работы А. Л. Тахтаджяна (1987), Р. В. Камелина $(2002,2004,2005)$. Ареалы видов рода Geranium АГС разделены на 11 типов, объединенных в 3 хорологические группы (табл. 1).

Таблица 1

Распределение видов рода Geranium АГС по типам ареалов

\begin{tabular}{|c|c|c|}
\hline $\begin{array}{c}\text { № } \\
\Pi / \Pi\end{array}$ & Подрод, секция, подсекция, вид & Тип ареала \\
\hline \multicolumn{3}{|c|}{ Subgen. Geranium } \\
\hline \multicolumn{3}{|c|}{ Sect. Geranium } \\
\hline \multicolumn{3}{|c|}{ Subsect. Geranium } \\
\hline 1 & G. sylvaticum & Евросибирский \\
\hline 2 & G. laetum & Алтае-джунгарский \\
\hline 3 & G. rectum & Джунгаро-тяньшань-алайский \\
\hline \multicolumn{3}{|c|}{ Subsect. Albiflora } \\
\hline 4 & G. albiflorum & Алтае-джунгарский \\
\hline 5 & G. krylovii & Евразиатский \\
\hline 6 & G. malyschevii & Алтае-саянский \\
\hline \multicolumn{3}{|c|}{ Subsect. Pseudosibirica } \\
\hline 7 & G. pseudosibiricum & Североазиатский \\
\hline 8 & G. asiaticum & Урало-западносибирский \\
\hline \multicolumn{3}{|c|}{ Sect. Recurvata } \\
\hline \multicolumn{3}{|c|}{ Subsect. Recurvata } \\
\hline 9 & G. pratense & Палеарктический \\
\hline 10 & G. sergievskajae & Сибирский \\
\hline 11 & G. affine & Алтае-джунгарский \\
\hline 12 & G. transbaicalicum & Южносибирско-восточноазиатский \\
\hline 13 & $\begin{array}{l}\text { G. transbaicalicum subsp. } \\
\text { turczaninovii }\end{array}$ & Южносибирско-восточноазиатский \\
\hline \multicolumn{3}{|c|}{ Subsect. Collina } \\
\hline 14 & G. collinum & Евро-древнесредиземноморский \\
\hline 15 & G. saxatile & Евро-древнесредиземноморский \\
\hline \multicolumn{3}{|c|}{ Sect. Sibirica } \\
\hline 16 & G. sibiricum & Голарктический \\
\hline \multicolumn{3}{|c|}{ Sect. Trygonium } \\
\hline 17 & G. schrenkianum & Туранский \\
\hline \multicolumn{3}{|c|}{ Sect. Tuberosa } \\
\hline 18 & G. transversale & Турано-джунгарский \\
\hline \multicolumn{3}{|c|}{ Subgen. Robertium } \\
\hline \multicolumn{3}{|c|}{ Sect. Batrachioides } \\
\hline 19 & G. pusillum & Евро-древнесредиземноморский \\
\hline 20 & G. rotundifolium & Евро-древнесредиземноморский \\
\hline \multicolumn{3}{|c|}{ Sect. Divaricata } \\
\hline 21 & G. divaricatum & Евро-древнесредиземноморский \\
\hline \multicolumn{3}{|c|}{ Sect. Ruberta } \\
\hline 22 & G. robertianum & Палеарктический дизьюнктивный \\
\hline
\end{tabular}


Циркумбореальная хорологическая группа. 1. Голарктический тип ареала включает виды, встречающиеся во внетропических частях Евразии и Северной Америки, характерные для Голарктического флористического царства. Широко распространен на территории всей Голарктики вид G. sibiricum. 2. Палеарктический тип ареала имеет область распространения, охватывающую умеренные и субтропические области Голарктического царства флоры в пределах Старого Света, за исключением юга Аравийского полуострова, Индостана и Индокитая, с включением Северной Африки, к югу примерно до тропика Рака. Вид с собственно палеарктическим ареалом - G. pratense, палеарктический дизъюнктивный ареал имеет вид лесного флороценотипа - G. robertianum. 3. Евразиатский тип ареала включает в основном лесную и высокогорную территорию Европы, Урала и Азии. Характерен для вида горных флороценотипов (альпийских травников, тундр) G. krylovii. 4. Евросибирский тип ареала включает виды, распространенные на территории Европы, на Урале и в западной части Северной Азии, где проходит восточная граница распространения. Распространение видов в основном очерчивается границами Евросибирской флористической подобласти Циркумбореальной области по Р. В. Камелину (2002). Собственно евросибирский ареал имеет вид G. sylvaticum. Урало-западносибирский ареал - у вида G. asiaticum. 5. Североазиатский тип ареала представлен на территории Северной Азии за исключением тихоокеанской части побережья - южной части русского Дальнего Востока, Камчатки, Сахалина и Курильских островов и других прилежащих территорий, относимых к восточно-азиатским. Североазиатский ареал имеет вид лугово-лесного флороценотипа - G. pseudosibiricum. 6. Сибирский тип ареала характеризуется распространением на территории Сибири с незначительными иррадиациями в лесную зону Казахстана. Такой ареал характерен для вида лугово-лесного флороценотипа - G. sergievskajae. 7. Алтае-саянский тип ареала включает виды, распространенные по горам Алтая и Саян. Этот тип ареала имеет вид G. malyschevii. 8. Алтае-джунгарский тип ареала характерен для видов с распространением по горам Алтая и Джунгарии. Объединяет субэндемики Большого Алтая: G. laetum, G. albiflorum, G. affine.

Древнесредиземноморская хорологическая группа. 9. Евро-древнесредиземноморский тип ареала объединяет ареалы, имеющие широкое простирание в степной и аридной полосе от Паннонии и вообще от Центральной Европы, через Древнее Средиземье до Забайкалья и Восточной Монголии. Такой тип ареала характерен для G. collinum, G. saxatile, G. pusillum, G. rotundifolium, G. divaricatum. 10. Туранский тип ареала объединяет типы ареалов, находящиеся на территории Туранской провинции Сахаро-гобийской области Древнесредиземноморского подцарства. К нему относятся виды: турано-джунгарский $G$. transversale, джунгаро-тяньшань-алайский $G$. rectum и собственно туранский G. schrenkianum, распространенный на территории Казахстана.

Восточноазиатская хорологическая группа. 11. Южносибирско-восточноазиатский тип ареала включает виды с ареалами, захватывающими территорию Южной Сибири, прилегающие районы Северной Монголии и внетропической части Восточной Азии. Этот тип ареала характерен для видов G. transbaicalicum и G. transbaicalicum subsp. turczaninovii.

В основу эколого-ценотического анализа рода Geranium АГС положена схема, предложенная Л. И. Малышевым и Г. А. Пешковой (1984) для Байкальской Сибири с учетом особенностей Алтайской горной страны (Куминова, 1960; Огуреева, 1980, Ревушкин, 1988; Камелин, 2005). Флористические комплексы объединяют эколого-ценотические группы, элементы, приуроченные к сообществам различных типов, соответственно совокупности экологических факторов в пределах экотопов (Галанин, 1973; Юрцев, Камелин, 1991).

Таксоны рода Geranium АГС разделены нами на 3 флористических комплекса: луговой, лесной, синантропный с подразделениями на эколого-ценотические группы. Ценотическая приуроченность видов определялась по результатам полевых исследований с учетом информации из литературных источников (табл. 2).

Самый крупный флористический комплекс по количеству видов - луговой (13 или 59,1\%), объединяющий три эколого-ценотические группы. К горно-лесо-луговой принадлежат виды, произрастающие в лесном горном поясе, а также на субальпийских и частично альпийских лугах, изредка в горных тундрах: G. albiflorum, G. krylovii, G. malyschevii, G. pseudosibiricum из секции Geranium, G. sergievskajae, G. saxatile из секции Recurvata. G. albiflorum - субэндемик АГС, произрастающий в горно-лесном поясе, на субальпийских лугах и в редколесьях. 
«Проблемы ботаники Южной Сибири и Монголии» - XVIII Международная научно-практическая конференция

Таблица 2

Флористические комплексы и эколого-ценотические группы видов рода Geranium АГС

\begin{tabular}{|c|c|c|c|}
\hline $\begin{array}{c}\text { Флористические } \\
\text { комплексы и эколого- } \\
\text { ценотические группы }\end{array}$ & Виды & $\begin{array}{c}\text { Количество видов } \\
\text { в эколого-ценоти- } \\
\text { ческих группах }\end{array}$ & $\begin{array}{c}\text { Количество и доля } \\
\text { видов от всех видов } \\
\text { гераней флоры АГС, \% }\end{array}$ \\
\hline $\begin{array}{l}\text { I. Луговой } \\
\text { 1. горно-лесо-луговая }\end{array}$ & $\begin{array}{l}\text { G. albiflorum, G. krylovii, } \\
\text { G. malyschevii, G. pseudosibiricum, } \\
\text { G. sergievskajae, G. affine, } \\
\text { G. saxatile }\end{array}$ & 7 & \multirow{3}{*}{$13 / 59,1$} \\
\hline 2. лугово-степная & $\begin{array}{c}\text { G. transbaicalicum, } \\
\text { G. transbaicalicum subsp. } \\
\text { turczaninovii, G. transversale }\end{array}$ & 3 & \\
\hline 3. лесо-луговая & $\begin{array}{l}\text { G. pratense, G. collinum, } \\
\text { G. schrenkianum }\end{array}$ & 3 & \\
\hline $\begin{array}{l}\text { II. Лесной } \\
\text { 1. лесная }\end{array}$ & $\begin{array}{l}\text { G. sylvaticum, G. laetum, } \\
\text { G. rectum, G. asiaticum, } \\
\text { G. robertianum }\end{array}$ & 5 & $5 / 22,7$ \\
\hline $\begin{array}{l}\text { III. Синантропный } \\
\text { 1. апофитная }\end{array}$ & $\begin{array}{l}\text { G. sibiricum, G. rotundifolium, } \\
\text { G. divaricatum }\end{array}$ & 3 & \multirow{2}{*}{$4 / 18,2$} \\
\hline 2. адвентивная & G. pusillum & 1 & \\
\hline
\end{tabular}

G. krylovii - это вид, занимающий широкий ареал, от Северо-Востока европейской части России до бассейна реки Алдан в Якутии. Переносит низкие температуры, является криофильным, встречается на территории Полярного Урала и Таймыра, на территории Алтая предпочитает светлохвойные и черневые леса, субальпийские луга и редколесья, альпийские луга, встречается в горных тундрах. Близкий к нему вид - G. malyschevii, имеющий на территории АГС юго-западную границу ареала, также предпочитает высокогорья и черневые, лиственные и смешанные леса, места избыточного увлажнения: горные луга и окраины болот, однако его ареал значительно меньше - охватывает территорию гор Западной и Восточной Сибири, обнаружен в Северной Монголии (окр. оз. Хубсугул). G. sergievskajae вид, обитающий на горных лугах ниже границы леса, а также на лесных полянах, опушках, горных речных поймах. G. affine - вид, родственный G. pratense, субэндемик АГС, встречается в лесном поясе, по опушкам и лугам, остепненным южным склонам, горным степям, поднимается до субальпийских лугов.

Лугово-степная эколого-ценотическая группа включает три таксона. G. transbaicalicum и G. transbaicalicum subsp. turczaninovii из секции Recurvata обитают в горных остепненных лугах, луговых степях, на луговых открытых склонах и по долинам рек. Оба таксона имеют западную границу ареала на территории АГС. Третий вид - G. transversale из секции Tuberosa - турано-джунгарский вид лугово-степных равнин, низкогорий и предгорий. Встречается также на сухих склонах среди кустарниковых зарослей, иногда сорничает.

К лесо-луговой эколого-ценотической группе принадлежит G. pratense - палеарктический вид из секции Recurvata, предпочитающий влажные луговые сообщества, встречающийся также на лесных полянах и опушках, иногда - на залежах и нарушенных местообитаниях. Другой вид - G. collinum из этой же секции, имеющий широкий европейско-древнесредиземноморский ареал, произрастает на равнинных лугах, по долинам рек и озер, часто соленых, на склонах гор. Туранский вид G. schrenkianum из секции Trygonium также отнесен нами к этой эколого-ценотической группе. Встречается на влажных лужайках, болотцах, наносах речек и ручьев. На территории Казахстанского Алтая проходит северная граница его ареала.

Лесной флористический комплекс объединяет 5 видов (22,7 \%) бореальной эколого-ценотической группы, произрастающих преимущественно в светлохвойных и смешанных лесах, на лесных опушках и лесных лугах, как равнинных, так и низкогорных и среднегорных: G. sylvaticum, G. laetum, G. rectum, G. asiaticum, G. robertianum. 
G. sylvaticum - широко распространенный вид с евросибирским ареалом, восточной границей распространения которого является восточное побережье оз. Байкал. На территорию АГС заходит краем ареала, и здесь встречается в светлохвойных и смешанных лесах, на лесных опушках и лугах на равнинах, в предгорьях и низкогорьях. G. laetum - алтае-джунгарский вид, субэндемик АГС, распространенный в горно-лесном поясе, по зарослям кустарников, на лесных лугах. Изредка появляется в субальпике. G. rectum - джунгаро-тяньшань-алайский вид горно-лесного пояса. На территорию АГС заходит северным краем ареала. G. asiaticum - вид с урало-западносибирским ареалом, произрастающий в светлохвойных и смешанных лесах, на лесных лугах, на луговых склонах. Это преимущественно равнинный вид, изредка поднимается в предгорья и низкогорья. G. robertianum - на территории АГС преимущественно лесной вид черневой тайги и липовых лесов. Встречается также на лесных лугах, луговых склонах, на выходах скал. Имеет палеарктический дизъюнктивный ареал.

Синантропный флористический комплекс представлен 4 видами (18,2 \%), которые встречаются в местах постоянного или временного проживания населения. Он состоит из двух эколого-ценотических групп - апофитной (местной) и адвентивной (пришлой). Апофиты могут расти и в дикой природе, но тяготеют к антропогенным ландшафтам. К ним относится три вида - G. sibiricum из секции Sibirica, G. rotundifolium из секции Batrachioides, G. divaricatum из секции Divaricata. G. sibiricum - вид, имеющий евразиатский ареал, расселяется почти повсеместно, где есть человек - в садах, парках, огородах, на сорных местах. В естественных местообитаниях встречается в луговых сообществах, предположительно имеет восточноазиатские корни. G. rotundifolium и G. divaricatum - европейско-древнесредиземноморские виды, на территорию АГС заходящие с территории Казахстана и встречающиеся тут в садах, огородах, парках, по сорным местам. Естественные местообитания G. rotundifolium - щебнистые склоны, выходы скал, кустарниковые заросли; G. divaricatum встречается в кустарниковых зарослях, на каменистых осыпях и щебнистых склонах гор. В Средней Азии поднимается до высоты 2000 м над ур. м. Адвентивный вид G. pusillum - имеет евро-древнесредиземноморский ареал. Встречается в огородах, садах, вдоль дорог, по сорным местам, в кустарниковых зарослях.

Таким образом, при проведении экологического анализа таксоны рода Geranium АГС разделены на 3 флористических комплекса: луговой, лесной и синантропный с подразделениями на 6 эколого-ценотических групп. Более половины видов относятся к горно-лесолуговой и бореальной эколого-ценотической группе. Важную роль в растительных группировках Алтая играют такие виды как G. albiflorum, G. krylovii, G. laetum, G. pseudosibiricum, G. asiaticum, G. pratense, G. sergievskajae, G. affine.

Ареалы видов рода Geranium АГС разделены на три хорологические группы: циркумбореальную (12 видов), древнесредиземноморскую (8 видов) и восточноазиатскую (2 вида) с 11 типами ареалов. К циркумбореальной группе относятся бореальные виды подрода Geranium: алтае-джунгарские субэндемичные G. laetum, G. albiflorum и G. affine, евразиатский G. krylovii, алтае-саянский G. malyschevii, североазиатский G. pseudosibiricum, урало-западносибирский G. asiaticum, сибирский G. sergievskajae. Девять видов имеют аллохтонное происхождение на территории АГС. Три субэндемика Алтайской горной страны - G. laetum, G. albiflorum, G. affine имеют автохтонное происхождение. Все представители подрода Robertium, произрастающие на территории АГС, относятся к древнесредиземноморской хорологической группе. К этой же группе мы относим туранский G. schrenkianum из секции Trygonium подрода Geranium, родственный средиземноморскому G. columbinum, не заходящему на территорию Алтая, а также турано-джунгарский G. transversale из секции Tuberosa; вид типовой секции джунгаро-тяньшане-алайский G. rectum; виды секции Recurvata: евро-древнесредиземноморские виды G. collinum и G. saxatile подсекции Collina. Все они имеют аллохтонное происхождение на территории АГС. К видам восточноазиатской группы относятся южносибирско-восточноазиатские G. transbaicalicum и G. transbaicalicum subsp. turczaninovii. На территории АГС виды и подвид аллохтонные.

Алтайская горная страна является одним из центров разнообразия рода Geranium, который включает 21 вид и 1 подвид из 2 подродов, 8 секций и 5 подсекций. 9 видов имеют древнесредиземноморское происхождение, 8 - циркумбореальное и 3 , предположительно, восточноазиатское. Восемнад- 
цать видов и 1 подвид аллохтонные на территории АГС, 3 субэндемика АГС G laetum, G. albiflorum, G. affine автохтонные. Важную роль в растительных группировках Алтая играют такие виды как G. albiflorum, G. krylovii, G. laetum, G. pseudosibiricum, G. asiaticum, G. pratense, G. sergievskajae, G. affine.

\section{ЛИТЕРАТУРА}

Галанин А. В. Эколого-ценотические элементы конкретной флоры (их выделение и анализ) // Бот. журн., 1973. - Т. 58. - № 11. - C. 1608-1618.

Камелин P. B. Материалы по истории флоры Азии (Алтайская горная страна). - Барнаул: Изд-во Алт. ун-та, 1998. - 240 c.

Камелин P. В. Важнейшие особенности сосудистых растений и флористическое районирование России // Проблемы ботаники Южной Сибири и Монголии: материалы I Междунар. науч.-практ. конф. (26-28 ноября 2002 г., Барнаул). - Барнаул: изд-во «Азбука», 2002. - С. 36-41.

Камелин Р. В. Флора [России] / Р. В. Камелин // Большая Российская энциклопедия. Том Россия / Под ред. Ю. С. Осипова. - М.: Науч. изд-во «Большая Российская энциклопедия», 2004. - С. 84-88.

Камелин Р. В. Флора Алтая. Том 1 / Р. В. Камелин, М. Г. Куцев, Д. В. Тихонов, Д. Н. Шауло, А .И. Шмаков, R. L. L. Viane / под ред. Р. В. Камелина. - Барнаул: АзБука, 2005. - 340 с.

Кожевников A.E. Сытевые (семейство Суреraceae Juss.) Дальнего Востока России (современный таксономический состав и основные закономерности его формирования). - Владивосток: Дальнаука, 2001. - 275 с.

Куминова A. В. Растительный покров Алтая. - Новосибирск: РИО СО АН СССР, 1960. - 450 с.

Малышев Л. И., Пешкова Г. А. Особенности и генезис флоры Сибири (Предбайкалье и Забайкалье). - Новосибирск, 1984. - 265 с.

Огуреева Г. Н. Ботаническая география Алтая. - М.: Наука, 1980. - 190 с.

Пешкова Г. А. Семейство Geraniaceae // Флора Сибири: Geraniaceae - Cornaceae. - Новосибирск: Наука, 1996. - T. 10. - C. 8-22.

Попов М. Г. Основы флорогенетики // Филогения, флорогенетика, флорография, систематика: Избр. тр. В 2-х ч. - Киев, 1983. - Ч. 1. - С. 132-237.

Ревушики А. С. Высокогорная флора Алтая. - Томск: Изд-во Томского ун-та, 1988. - 319 с.

Тахтаджян А. Л. Система магнолиофитов. - Л.: Наука, 1987. - С. 185-188.

Трошкина В. И. Ареалы сибирских видов из секции Geranium рода Geranium (Geraniaceae) // Тезисы докладов III (XI) Международной Ботанической конференции молодых ученых в Санкт-Петербурге (4-9 октября 2015 г.). - СПб., 2015. - С. 139-140.

Трошкина В. И. Заметки по систематике и хорологии Geranium pseudosibiricum и близких видов (Geraniaceae) // Растит. мир Азиатской России, 2016а. - № 3 (23). - С. 22-32.

Трошкина В.И. О видовой самостоятельности Geranium sergievskajae (Geraniaceae) // Новости сист. высш. раст., 2016б. - Т. 47. - С. 31-39.

Трошкина В. И. Систематика и хорология Geranium albiflorum и родственных ему видов (Geraniaceae) // Растительный мир Азиатской России, 2017. - № 3(27). - С. 22-33.

Цыренова Д. Ю. Герани (Geranium) в бассейне Амура. Систематика, распространение, филогения. - Хабаровск: Изд-во ДВГГУ, 2007. - 182 с.

Юрцев Б. А., Камелин Р. В. Основные понятия и термины флористики. - Пермь: Пермский государственный университет, 1991. $-80 \mathrm{c}$.

Aedo C., Pando F., Garmendia F. M. World checklist of Geranium L. (Geraniaceae) // Anales Jard. Bot. Madrid, 1998. - Vol. 56. - № 2. - P. 211-252.

Hulten E. Flora of Alaska and Neighboring Territories: A manual of the Vascular Plants. - Stanford: Stanford University Press, 1968. - $1032 \mathrm{p}$.

Meusel H., Jäger E., Rauschert S., Weinert E. Vergleichende Chorologie der Zentraleuropäischen Flora. - Jena: Veb Gustav Fischer Verlag, 1978. - S. 259-263.

Müller J. Fossil pollen records of extant angiosperms // Bot. review, 1981. - Vol. 47. - № 1. - P. 1-146.

Robertson R. The genera of Geraniaceae in the southeastern United States // Journ. Arnold. Arbor., 1972. - Vol. 53. - № 2. - P. 182-201.

Yeo P. F. The biology and systematics of Geranium, sections Anemonifolia Knuth and Ruberta Dum. // Bot. Journ. Linn. Soc., 1973. - Vol. 67. - № 4. - P. 285-345.

Yeo P. F. Fruit-discharge-type in Geranium (Geraniaceae): its use in classification and its evolutionary implications // Bot. J. Linn. Soc., 1984. - Vol. 89. - P. 1-36. 